in circulating B cells (21), and neural cells expressing p75 NGFR survive in media containing serum (Fig. 2). The mechanism by which unbound $\mathrm{p} 75^{\mathrm{NGFR}}$ or other members of this receptor superfamily lead to neural cell death is unknown. However, the structural and functional relation between $p 75^{\text {NGFR }}$ and TNFR I and II suggests that they may have similar mechanisms of action.

The highest level of expression of $\mathrm{p} 75^{\mathrm{NGFR}}$ in the central nervous system occurs in cholinergic neurons of the nucleus basalis of Meynert, the cells most severely affected in Alzheimer's disease. These cells continue to express normal (22) or supranormal (23) amounts of $\mathrm{p} 75^{\mathrm{NGFR}} \mathrm{mRNA}$ and protein during the neuronal degeneration associated with Alzheimer's disease. In contrast, cholinergic cells of the brainstem that resemble those of the nucleus basalis morphologically, but do not express p75 NGFR (24), do not degenerate in Alzheimer's disease (25).

\section{REFERENCES AND NOTES}

1. R. Klein, S. Jing, V. Nanduri, E. O'Rourke, M. Barbacid, Cell 65, 189 (1991); B. L. Hempstead, D. Martin-Zanca, D. R. Kaplan, L. F. Parada, M. V. Chao, Nature 350, 678 (1991); C. F. Ibañez et al., Cell 69, 329 (1992)

2. N. Y. Ip et al., Neuron 10, 137 (1993)

3. T. J. Schall et al., Cell 61, 361 (1990)

4. C. A. Smith et al., Science 248, 1019 (1990).

5. B. C. Trauth et al., ibid. 245, 301 (1989); N. Itoh et al., Cell 66, 233 (1991)

6. Y. J. Liu et al., Nature 342, 21 (1989); J. Banchereau, P. de Paoli, A. Vallé, E. Garcia, F. Rousset, Science 251, 70 (1991).

7. M. Durand, D. C. Chugani, M. Mahmoudi, M. E. Phelps, Soc. Neurosci. Abstr. 16, 40 (1990)

8. J. P. Morgenstern and $\mathrm{H}$. Land, Nucleic Acids Res. 18, 3587 (1990)

9. L. T. Zhong, S. P. Mah, R. H. Edwards, D. E. Bredesen, Soc. Neurosci. Abstr. 18, 44 (1992); L. T. Zhong et al., Proc. Natl. Acad. Sci. U.S.A. 90, 4533 (1993).

10. M. E. Greenberg, R. Brackenbury, G. M. Edelman, Proc. Natl. Acad. Sci. U.S.A. 81, 969 (1984).

11. J. F. R. Kerr and B. V. Harmon, in Apoptosis: The Molecular Basis of Cell Death, L. D. Tomei and F. O. Cope, Eds. (Cold Spring Harbor Laboratory Press, Cold Spring Harbor, NY, 1991), vol. 3, p. 321.

12. A. Rukenstein, R. E. Rydel, L. A. Greene, J. Neurosci. 11, 2552 (1991); S. P. Mah et al., J. Neurochem. 60, 1183 (1993)

13. PC12 cells were maintained in Dulbecco's minimum essential medium (DMEM; Gibco) containing $5 \%$ horse serum and $5 \%$ supplemented calf serum (Hyclone), in $12 \% \mathrm{CO}_{2}$ at $37^{\circ} \mathrm{C}$. Cells were mutagenized with $10 \mathrm{mM}$ ethyl methanesulfonate for 6 hours and then washed with $2 \times 10 \mathrm{ml}$ of medium. After growing for 10 days, cells were trypsinized and subcultured into 36 plates at an approximate density of $10^{4}$ cells per plate. The cells were grown for 10 days (approximately five divisions) and then treated with NGF $(25 \mathrm{ng} / \mathrm{ml})$ for 5 days. Groups of clonally derived cells that did not respond to NGF by extending neurites were isolated, subcloned, and then tested for the absence of NGF-induced neurite outgrowth and the presence (or absence) of p75 NGFR by Northern (RNA) and protein immunoblot analysis. The two subclones used in these experiments were the NRA5 subclone, which does not express p75NGFR, and NR5D, which does express p75 NGFR.

14. S. Rabizadeh et al., unpublished data

15. A. Sutter, R. J. Riopelle, R. M. Harris-Warrick, E.
Shooter, J. Biol. Chem. 254, 5972 (1979)

16. R. Levi-Montalcini, Harvey Lect. 60, 217 (1966) Science 237, 1154 (1987).

17. T. H. Large et al., Neuron 2, 1123 (1989)

18. D. P. Martin et al., J. Cell Biol. 106, 829 (1988).

19. K. Schulze-Osthoff et al., J. Biol. Chem. 267, 5317 (1992).

20. N. Itoh et al., Cell 266, 233 (1991).

21. J. P. DiSanto, J. Y. Bonnefoy, J. F. Gauchat, A Fischer, G. de Saint Basile, Nature 361, 541 (1993).

22. M. Goedert, A. Fine, D. Dawbarn, G. K. Wilcock M. V. Chao, Mol. Brain Res. 5, 1 (1989); J. H. Kordower, D. M. Gash, M. Bothwell, L. Hersh, E. J. Mufson, Neurobiol. Aging 10, 67 (1989).

23. P. Ernfors, N. Linderfors, V. Chan-Palay, H. Persson, Dementia 1, 138 (1990).

24. N. J. Woolf, E. Gould, L. L. Butcher, Neuroscience 30, 143 (1989)

25. N. J. Woolf, R. W. Jacobs, L. L. Butcher, Neurosci. Lett. 96, 277 (1989).

26. P. Chomczynski and N. Sacchi, Anal. Biochem. 162, 156 (1987).

27. S. P. Mah et al., J. Neurochem. 60, 1183 (1993).

28. The p75 NGFR CDNA in pUC9 was digested with Sal I, filled in with Klenow fragment and deoxynucleotide triphosphates, and then digested with Bgl II. The 1.7-kb fragment containing the entire open reading frame of $\mathrm{p} 75^{\text {NGFR }}$ was then ligated into pUC18 that had been digested with Sma and Bam HI. The resulting plasmid was digested with Eco 47III and Sal I and ligated into pBabepuro $(8)$ that had been cut with Sna $\mathrm{BI}$ and Sal I, to create pBabe-puro-p75 NGFR. CSM 14.1 cells (7) are rat nigral neural cells immortalized with the temperature-sensitive large $T$ antigen of SV40. These cells express tyrosine hydroxylase, neuronspecific enolase, and neurofilament (NF-L). CSM 14.1 cells were transfected with pBabe-purop75 NGFR with the cationic lipid DOTAP (Boehringer Mannheim, Inc.) and then selected in puromycin $(7 \mu \mathrm{g} / \mathrm{ml})$. The comparison of single colonies can introduce bias into the results (9), but this was obviated by comparison of entire pools of stable transfectants (9); therefore, pools of stable transfectants (populations including more than 100 separate colonies) with pBabe-puro-p75 NGFR were compared with pools of pBabe-puro transfectants. Cells were grown in DMEM with fetal bovine serum (FBS) (10\%) at $34^{\circ} \mathrm{C}$ in $5 \% \mathrm{CO}_{2}$. Total RNA was prepared by the method of Chomczynski (26), and electrophoresis was carried out in formaldehyde gels. After Northern transfer to nylon, ${ }^{32}$-labeled probes for p75 NGFR (1-kb cDNA fragment, digested with Stu I), Trk A (0.5-kb CDNA fragment, digested with Xho I), and $\gamma$-actin were hybridized sequentially. Blots were exposed to film for 24 hours for the p75NGFR and Trk A probes and for 2 hours for the $\gamma$-actin probe. For immunocytochemistry, cells were fixed in paraformaldehyde (4\%) for $15 \mathrm{~min}$ and permeabilized in $0.1 \%$ Triton $X-100$. Immunocytochemistry was done as described (27), with a polyclonal antibody $(1: 2500)$ to purified p75 NGFR. As controls, primary antibody was omitted and control transfectants were stained; both of these controls showed a similar lack of staining.

29. M. J. Radeke, T. P. Misko, C. Hsu, L. A. Herzenberg, E. M. Shooter, Nature 325, 593 (1987).

30. We thank E. Shooter for the p75 NGFR CDNA and hybridoma cells secreting the 192 immunoglobulin $\mathrm{G}$ mAb, G. Weskamp for the polyclonal anti- $\infty$ body to p75 NGFR, $H$. Land for the pBabe-puro + expression vector, M. Cohen for the R2 cells, M. I Durand for the CSM14.1 cells, E. Koo for the APP $_{751}$ CDNA, T. Örd for technical assistance, and R. Edwards and B. Howard for thoughtful discussions. Supported by a pilot grant from the $\frac{\mathrm{c}}{\mathrm{O}}$ Alzheimer's Disease and Related Disorders Association, NIH grant AG10671 (to D.E.B.), and NIH grant NS10928 (to L.L.B.)

16 February 1993; accepted 3 May 1993

\title{
Redundant Mechanisms of Calcium-Induced Calcium Release Underlying Calcium Waves During Fertilization of Sea Urchin Eggs
}

\author{
Antony Galione, ${ }^{*}$ Alex McDougall, William B. Busa, Nick Willmott, \\ Isabelle Gillot, Michael Whitaker
}

Propagating $\mathrm{Ca}^{2+}$ waves are a characteristic feature of $\mathrm{Ca}^{2+}$-linked signal transduction pathways. Intracellular $\mathrm{Ca}^{2+}$ waves are formed by regenerative stimulation of $\mathrm{Ca}^{2+}$ release from intracellular stores by $\mathrm{Ca}^{2+}$ itself. Mechanisms that rely on either inositol trisphosphate or ryanodine receptor channels have been proposed to account for $\mathrm{Ca}^{2+}$ waves in various cell types. Both channel types contributed to the $\mathrm{Ca}^{2+}$ wave during fertilization of sea urchin eggs. Alternative mechanisms of $\mathrm{Ca}^{2+}$ release imply redundancy but may also allow for modulation and diversity in the generation of $\mathrm{Ca}^{2+}$ waves.

$T_{\text {ransient increases in the concentration of }}$ calcium ions $\left(\left[\mathrm{Ca}^{2+}\right]_{\mathrm{i}}\right)$ act as cell signals. In general, the signal shows spatial and temporal inhomogeneity and takes the form of waves or oscillations within the cell (1).

A. Galione and N. Willmott, Department of Pharmacology, Oxford University, Oxford OX1 3QT, United Kingdom.

A. McDougall, I. Gillot, M. Whitaker, Department of Physiology, University College London, London WC1E 6BT, United Kingdom.

W. B. Busa, Department of Biology, Johns Hopkins University, Baltimore, MD 21218.

*To whom correspondence should be addressed.
Several mechanisms have been proposed to account for regenerative $\mathrm{Ca}^{2+}$ release (2). Release of $\mathrm{Ca}^{2+}$ from internal stores can be stimulated by an increase in $\left[\mathrm{Ca}^{2+}\right]_{i}$; this process is termed $\mathrm{Ca}^{2+}$-induced $\mathrm{Ca}^{2+}$ release (CICR) (3). This $\mathrm{Ca}^{2+}$ release appears to be mediated by $\mathrm{Ca}^{2+}$ channels in the endoplasmic reticulum (ER) that are sensitive to cytoplasmic agonists, to $\left[\mathrm{Ca}^{2+}\right]_{\mathrm{i}}$, and to the amount of $\mathrm{Ca}^{2+}$ in the lumen of the ER (4). Two closely related $\mathrm{Ca}^{2+}$ channels with these properties are the inositol trisphosphate $\left(\mathrm{IP}_{3}\right)$ receptor $\left(\mathrm{IP}_{3} \mathrm{R}\right)(5)$ and the 

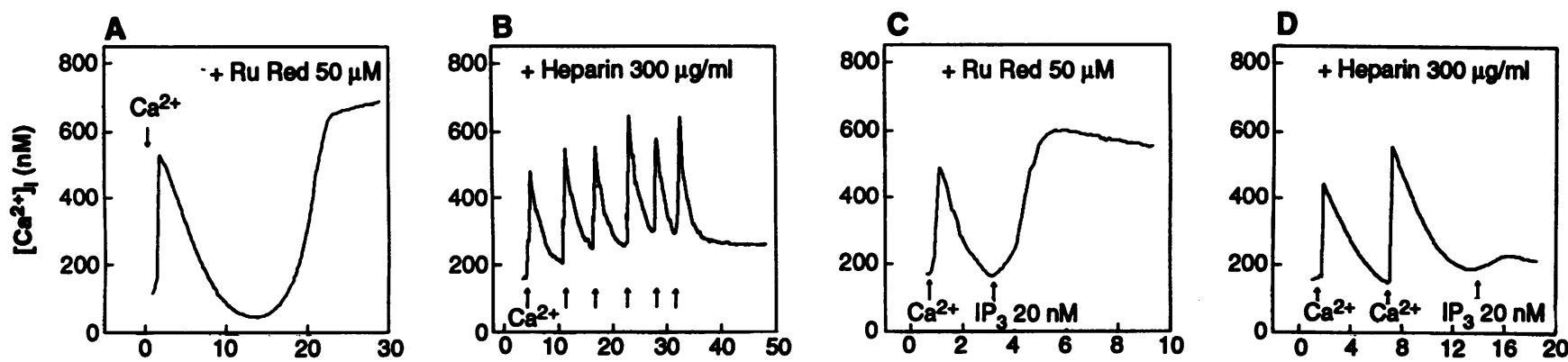

Fig. 1. Release of $\mathrm{Ca}^{2+}$ in Xenopus egg homogenates (28). (A and B) Spontaneous release of $\mathrm{Ca}^{2+}$ after loading of the $\mathrm{Ca}^{2+}$ stores. Calcium chloride ( $1 \mu \mathrm{l}, 10 \mathrm{nmol}$ ) was added to homogenates (1-ml portions), causing a transient increase in $\mathrm{Ca}^{2+}$. After each addition, the homogenate was allowed to sequester the added $\mathrm{Ca}^{2+}$ until the concentration of $\mathrm{Ca}^{2+}$ approached its initial value. Heparin $(300 \mu \mathrm{g} / \mathrm{ml})$ was $(B)$ or was not $(A)$ added to the homogenates; six additions of $\mathrm{Ca}^{2+}$ led to extensive loading of the $\mathrm{Ca}^{2+}$ stores without eliciting spontaneous release $(B)$. In $(A),(C)$, and $(E)$ the portions of homogenate were pretreated with ruthenium red (Ru Red) $(50 \mu \mathrm{M})$. (C and D) Enhanced $\mathrm{IP}_{3}$-induced $\mathrm{Ca}^{2+}$ release after loading of $\mathrm{Ca}^{2+}$ stores. Extracts were treated with $\mathrm{Ca}^{2+}$ and then with $\mathrm{IP}_{3}(20 \mathrm{nM})$ in the presence (D) or absence (C) of heparin $(300 \mu \mathrm{g} / \mathrm{ml})(29)$. (E and F) Thimerosal-induced $\mathrm{Ca}^{2+}$ release. Thimerosal $(50 \mu \mathrm{M})$ was added alone $(E)$ or in the presence of heparin $(300 \mu \mathrm{g} / \mathrm{ml})(\mathrm{F})$; five subsequent additions of $\mathrm{Ca}^{2+}$

$\operatorname{Tim}(\min )$ failed to elicit an overload response $(F)$.

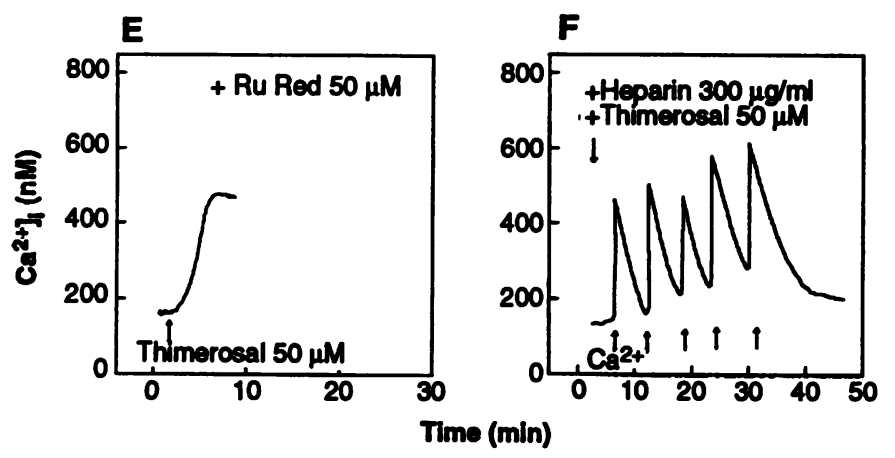

ryanodine receptor (RyR) (6), which appears to be regulated by cyclic adenosine diphosphate-ribose (cADPR) $(7,8)$.

Activating eggs have prominent spatial and temporal $\mathrm{Ca}^{2+}$ waves (9). We have pharmacologically dissected the waves of $\left[\mathrm{Ca}^{2+}\right]_{i}$ in both intact eggs and homogenates. We found that in frog and sea urchin eggs $\mathrm{Ca}^{2+}$ waves indeed have the same basis in CICR, but the mechanisms that have been put forward to account individually for $\mathrm{Ca}^{2+}$ wave propagation in various cell types were found to be acting together in sea urchin eggs. Simple egg homogenates sequester $\mathrm{Ca}^{2+}$ into vesicular stores and release it in response to $\mathrm{Ca}^{2+}$-releasing messengers $(7,10)$. We used homogenates to define the basic properties of CICR and to identify the release channel responsible.

Adenosine triphosphate (ATP)-dependent sequestration of added $\mathrm{Ca}^{2+}(7)$ overloaded the $\mathrm{Ca}^{2+}$ stores and led to spontaneous release of $\mathrm{Ca}^{2+}$ in frog egg homogenates after sequestration (Fig. 1A). Frog egg homogenates treated in this way were 50 times as sensitive to $\mathrm{IP}_{3}$ as untreated homogenates (Fig. 1, C and D) because
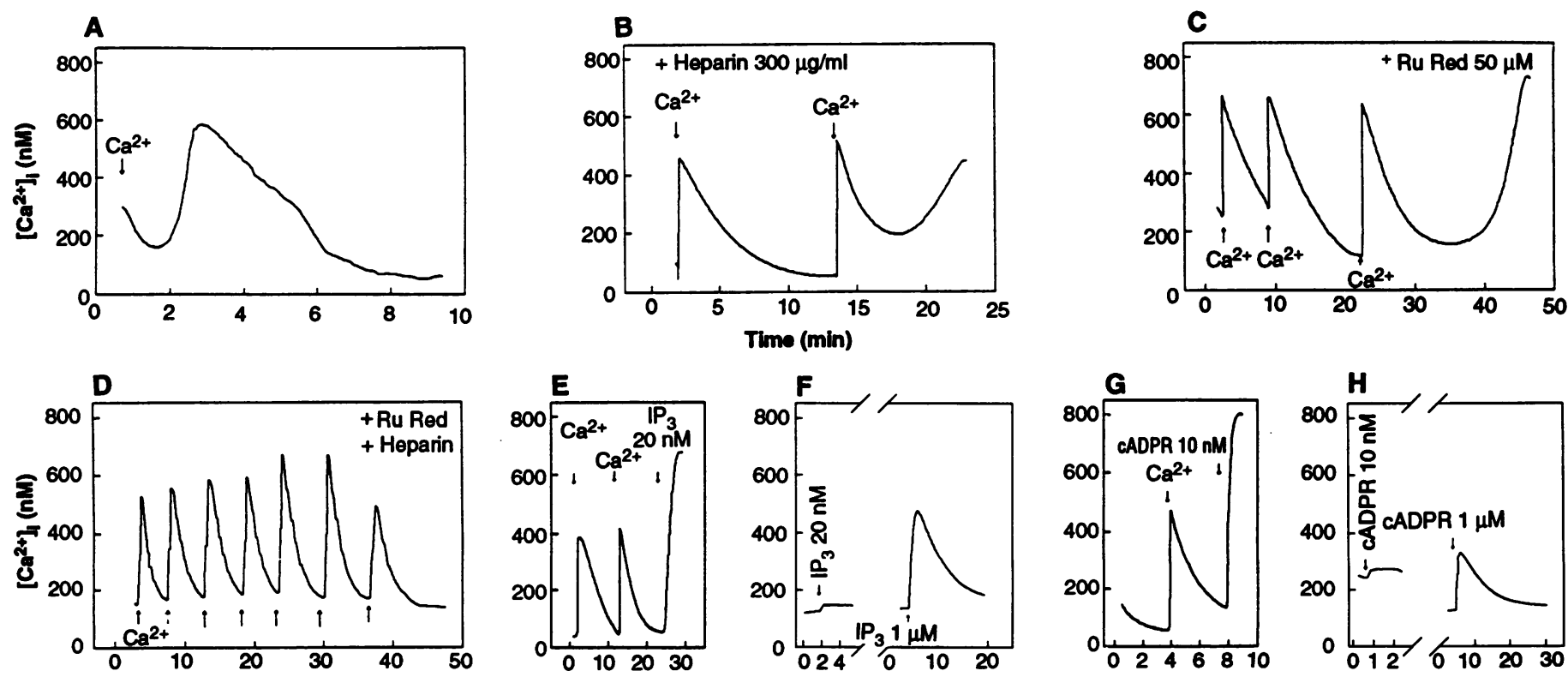

Fig. 2. Release of $\mathrm{Ca}^{2+}$ in sea urchin egg homogenates. (A through D) Spontaneous $\mathrm{Ca}^{2+}$ release after the addition of $\mathrm{Ca}^{2+}$. Portions of $\mathrm{Ca}^{2+}$ were added to a sea urchin egg homogenate (as in Fig. 1) without other additions $(A)$ or in the presence of heparin $(300 \mu \mathrm{g} / \mathrm{ml})(B)$, or ruthenium red $(50 \mu \mathrm{M})(C)$, or both agents together (D). (E through H) After $\mathrm{Ca}^{2+}$

Time (min)

addition, $20 \mathrm{nM} \mathrm{IP}_{3}(\mathrm{E})$ or $10 \mathrm{nM}$ cADPR $(\mathrm{H})$ was added. Homogenates without any added $\mathrm{Ca}^{2+}$ were also exposed to $\mathrm{IP}_{3}(\mathrm{~F}$ and $\mathrm{G})$ or to CADPR $(H)$ at the indicated concentrations. Methods were similar to those described in $(7,10)$. 
maximal $\mathrm{Ca}^{2+}$ release in untreated homogenates required $1.1 \pm 0.2 \mu \mathrm{M}$ (mean \pm SEM, $n=4) \mathrm{IP}_{3}$. The spontaneous release may result from the sensitization of the preparation to $\mathrm{IP}_{3}$ in the homogenate (11) because spontaneous release is blocked by the $I_{3} R$ antagonist heparin (Fig. 1B). The $\mathrm{IP}_{3} \mathrm{R}$ is also sensitized by treatment with oxidizing sulfhydryl reagents $(12,13)$. Addition of the sulfhydryl reagent thimerosal to a frog egg homogenate led to a large but initially slow $\mathrm{Ca}^{2+}$ release, the kinetics of which were similar to those of the $\mathrm{Ca}^{2+}$ release prompted by the addition of $\mathrm{Ca}^{2+}$ (Fig. 1E). The effect of thimerosal was also enhanced by $\mathrm{Ca}^{2+}$ loading (14). This effect appeared to result from sensitization of $\mathrm{IP}_{3} \mathrm{R}$ because thimerosal caused no $\mathrm{Ca}^{2+}$ release in the presence of heparin, even after repeated additions of $\mathrm{Ca}^{2+}$ (Fig. 1F).

We also added the RyR agonists cADPR, caffeine, and ryanodine to frog egg homogenates. They did not cause $\mathrm{Ca}^{2+}$ release, nor did pretreatment of homogenate portions with the RyR antagonist ruthenium red (14) affect CICR (Fig. 1, A, $\mathrm{C}$, and E). Egg homogenates therefore resemble intact frog oocytes in showing regenerative $\mathrm{Ca}^{2+}$ release through $\mathrm{IP}_{3} \mathrm{R}(15)$.

Sea urchin egg homogenates behaved differently. They too showed spontaneous release of $\mathrm{Ca}^{2+}$ and sensitization to $\mathrm{IP}_{3}$ after $\mathrm{Ca}^{2+}$ loading (Fig. 2, A and E), but the spontaneous release was not abolished by heparin (Fig. 2B). This spontaneous release might occur through RyR (16); caffeine and ryanodine caused $\mathrm{Ca}^{2+}$ release in sea urchin eggs $(7,17)$ and in homogenates (7), whereas ruthenium red blocked caffeineinduced $\mathrm{Ca}^{2+}$ release. Spontaneous release after addition of $\mathrm{Ca}^{2+}$ was detected in the presence of ruthenium red (Fig. 2C). However, spontaneous release was abolished if both ruthenium red and heparin were present (Fig. 2D), implying that both RyR and $\mathrm{IP}_{3} \mathrm{R}$ contribute to $\mathrm{CICR}$ in sea urchin egg homogenates. Loading stores in the sea urchin egg homogenate with $\mathrm{Ca}^{2+}$ sensitized $\mathrm{IP}_{3} \mathrm{R}$ to $\mathrm{IP}_{3}$ and $\mathrm{RyR}$ to $\mathrm{cADPR}$ by a factor of 50 or more (Fig. 2, E through $\mathrm{H}$ ). A similar sensitization of RyR occurred with caffeine, whereby loading stores with $\mathrm{Ca}^{2+}$ allowed a maximal $\mathrm{Ca}^{2+}$ release at 0.2 to $0.5 \mathrm{mM}$ caffeine (14), whereas 10 $\mathrm{mM}$ caffeine gave a maximal response in untreated homogenates (Table 1) (7). It has been suggested that thimerosal acts solely on $\mathrm{IP}_{3} \mathrm{R}(12)$ and also solely on RyR (18). Thimerosal caused release of $\mathrm{Ca}^{2+}$ in sea urchin egg homogenates (Fig. 3A). However, in the sea urchin egg homogenates, neither ruthenium red nor heparin alone prevented thimerosal's effects (Fig. 3, $B$ and $C)$. Together, ruthenium red and heparin did inhibit $\mathrm{Ca}^{2+}$ release in response to thimerosal (Fig. 3D). Thimerosal also
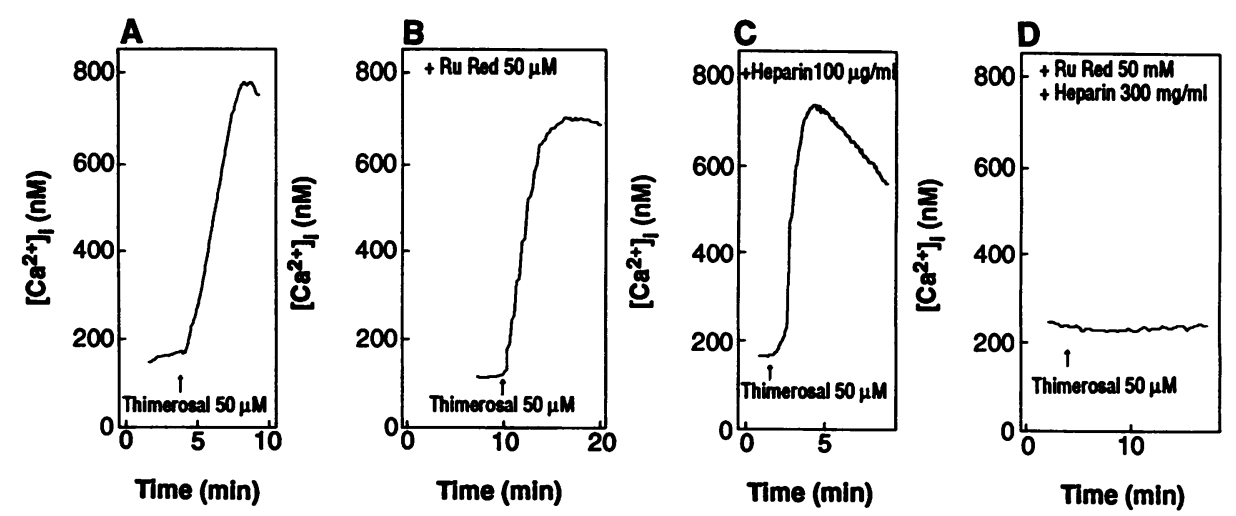

Fig. 3. (A through F) Effects of thimerosal on $\mathrm{Ca}^{2+}$ release in sea urchin egg homogenates. Release of $\mathrm{Ca}^{2+}$ was monitored in the presence of thimerosal $(50 \mu \mathrm{M})$ (A), thimerosal $(50 \mu \mathrm{M})$ together with ruthenium red $(50 \mu \mathrm{M})(\mathrm{B})$, thimerosal together with heparin $(100 \mu \mathrm{g} /$ $\mathrm{ml})(\mathrm{C})$, or both antagonists together (D). Homogenates were treated with thimerosal (Thim) $(20 \mu \mathrm{M})$ and $\mathrm{IP}_{3}(\mathrm{E})$ or CADPR $(F)$ at the indicated concentrations.
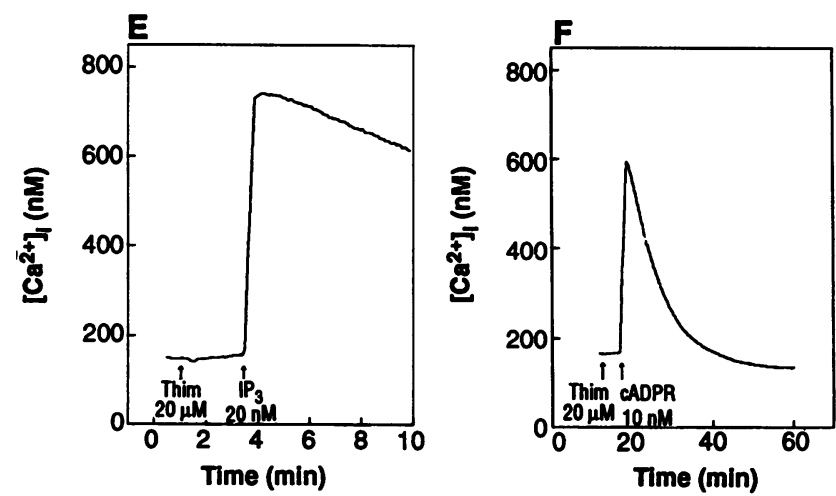

Table 1. The inhibition of $\mathrm{Ca}^{2+}$ release in sea urchin eggs and egg homogenates measured with fura 2 in response to the addition or microinjection of $I P_{3}$, CADPR, caffeine, or ryanodine (to the final concentration shown) was measured as described $(7,32)$. The $\mathrm{Ca}^{2+}$ transients are quantified as the peak height attained $(\mathrm{nM})$. Mean and SEM are shown, with the number of measurements in parentheses.

\begin{tabular}{lcc}
\hline $\begin{array}{c}\text { Calcium-releasing } \\
\text { agent }\end{array}$ & $\begin{array}{c}\text { Heparin } \\
(300 \mu \mathrm{g} / \mathrm{ml})\end{array}$ & $\begin{array}{c}\text { Ruthenium red } \\
(50 \mu \mathrm{M})\end{array}$ \\
\hline $\mathrm{IP}_{3}(1 \mu \mathrm{M})$ & Homogenates & \\
cADPR $(0.1 \mu \mathrm{M})$ & $25 \pm 8(4)$ & $510 \pm 38(4)$ \\
Caffeine $(10 \mathrm{mM})$ & $905 \pm 58(4)$ & $53 \pm 21(4)$ \\
Ryanodine $(600 \mu \mathrm{M})$ & $726 \pm 103(4)$ & $25 \pm 7(4)$ \\
& $569 \pm 95(4)$ & \\
$\mathrm{IP}_{3}(20 \mathrm{nM})$ & Eggs & $1290 \pm 320(5)$ \\
CADPR $(40 \mathrm{nM})$ & $190 \pm 30(3)$ & $250 \pm 40(4)$ \\
\hline
\end{tabular}

sensitized the homogenates to both $\mathrm{IP}_{3}$ (Fig. 3E) and cADPR (Fig. 3F). Thus, the effects of thimerosal and $\mathrm{Ca}^{2+}$ loading are similar, and thimerosal appears to affect both RyR and $I_{3} R$ (13). The sea urchin egg appears to have both a functional $\mathrm{IP}_{3} R$ and a functional RyR, whereas the frog egg has only a functional $\mathrm{IP}_{3} \mathrm{R}$.

In the frog egg $\mathrm{Ca}^{2+}$ waves can be induced by pricking the egg or by local application of a Ca ${ }^{2+}$ ionophore (19). The response to a $\mathrm{Ca}^{2+}$ ionophore indicates that a CICR mechanism is involved. We measured the $\mathrm{Ca}^{2+}$ waves after local application of the $\mathrm{Ca}^{2+}$ ionophore ionomycin (Fig. 4A, column D). Because we used a $\mathrm{Ca}^{2+}$-sensitive fluorescent dye and a confocal fluorescent microscope, we were able to visualize the
$\mathrm{Ca}^{2+}$ wave in an equatorial section through the egg. The wave crossed the cytoplasm and was not confined to the cortex. The wavefront was roughly spherical and traveled at 5 $\mu \mathrm{m} / \mathrm{s}(20)$. The $\left[\mathrm{Ca}^{2+}\right]_{i}$ was relatively uniform across the cytoplasm behind the wave. The $\mathrm{Ca}^{2+}$ wave at fertilization had very similar characteristics (Fig. 4A, column A). The wave started at the presumed site of sperm-egg interaction (sperm were added locally at the 10 o'clock position or upper left portion of the egg) and crossed the egg over a period of 5 to $6 \mathrm{~min}$. Inseminated eggs that had been microinjected with heparin showed only a local increase in $\left[\mathrm{Ca}^{2+}\right]_{i}$, presumably at the site of sperm-egg interaction, indicating that heparin had completely blocked the regenerative wave mechanism 
Fig. 4. (A) Images of $\mathrm{Ca}^{2+}$ waves in Xenopus eggs at fertilization and after parthenogenic activation (30). Confocal images of cytoplasmic $\mathrm{Ca}^{2+}$, with the $\mathrm{Ca}^{2+}$-sensitive dye calcium green. High $\mathrm{Ca}^{2+}$ concentrations are shown in red, and resting $\mathrm{Ca}^{2+}$ concentrations in blue. Successive images shown were recorded $64 \mathrm{~s}$ apart. The egg diameter is $1 \mathrm{~mm}$, and the image in each frame represents $0.7 \mathrm{~mm}$. The number column is time (in seconds). Column A: $\mathrm{Ca}^{2+}$ wave at fertilization. Column B: Insemination after micro-

injection of heparin $(300 \mu \mathrm{g} / \mathrm{ml})$. After $15 \mathrm{~min}$, ionomycin was applied to the same egg at the 9 o'clock position (column C). Column D: Image of a different egg, to which ionomycin was applied at the 10 o'clock position. (B) Corresponding $\mathrm{Ca}^{2+}$ waves at fertilization in sea urchin eggs $(31,32)$. The images shown were recorded $6.6 \mathrm{~s}$ apart. The egg is $100 \mu \mathrm{m}$ in diameter. Column 1: The fertilization wave started at the site of sperm entry (10 o'clock position) in all columns and crosses the egg over a period of $20 \mathrm{~s}$. Column 2: Egg microinjected with heparin (300 $\mu \mathrm{g} / \mathrm{ml}$ ) and then fertilized. Eggs were microinjected with ruthenium red alone (RR) $(50 \mu \mathrm{M})$ (column 3) or with ruthenium red and heparin (300
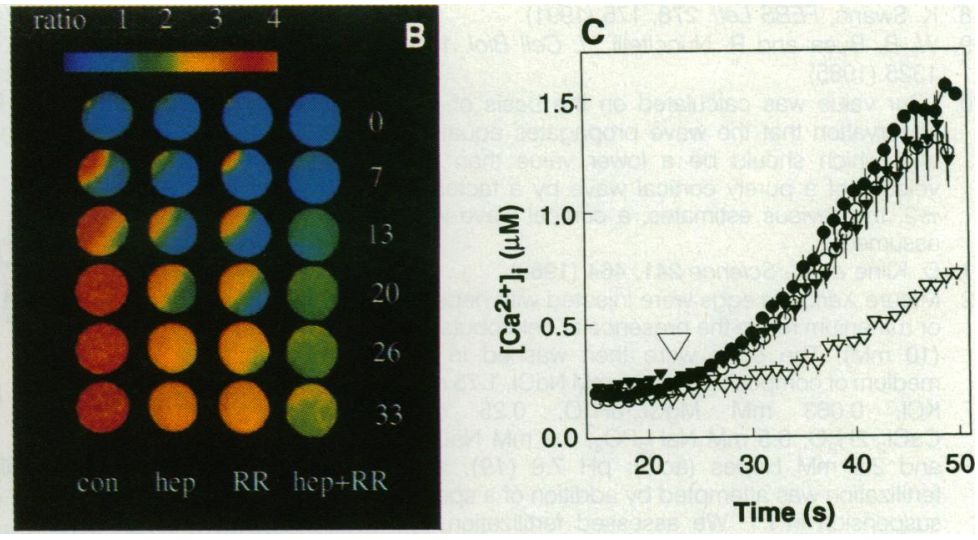

$\mu \mathrm{g} / \mathrm{ml}$ ) (column 4) and then fertilized. (C) Measurement of $\left[\mathrm{Ca}^{2+}\right]_{i}$ in single sea urchin eggs at fertilization with fura 2. Control fertilization (O); heparin $(300 \mu \mathrm{g} / \mathrm{ml})(\nabla) ; 50 \mu \mathrm{M}$ ruthenium red $(0)$; heparin $(300 \mu \mathrm{g} / \mathrm{ml})$ $+50 \mu \mathrm{M}$ ruthenium red $(\nabla)$. The error bars represent the standard error of the mean of five experiments. The large inverted triangle indicates the time at which an increase in $\left[\mathrm{Ca}^{2+}\right]$, was first detected. Because there were variable latencies for the initiation of responses, the traces were superimposed for comparison with the initiation of $\mathrm{Ca}^{2+}$ transients occurring at $22 \mathrm{~s}$.
(Fig. 4A, column B). When ionomycin was applied locally with a micropipette to the same egg, we saw a larger, local increase in $\left[\mathrm{Ca}^{2+}\right]_{\mathrm{i}}$ but no $\mathrm{Ca}^{2+}$ wave (Fig. 4A, column C). Heparin at a concentration of $100 \mu \mathrm{g} / \mathrm{ml}$ halved the wave velocity.

We verified our measurements of $\mathrm{Ca}^{2+}$ concentration by scoring egg activation with contraction of the pigment as a criterion (21). Heparin caused 50\% inhibition of egg activation at concentrations of 100 to $200 \mu \mathrm{g} / \mathrm{ml}$. Egg activation was effectively blocked by a heparin concentration of 300 $\mu \mathrm{g} / \mathrm{ml}$ with 4 out of 35 eggs activated upon insemination but was unaffected by ruthenium red at concentrations of up to $50 \mu \mathrm{M}$ with 25 out of 29 eggs activated upon insemination (22). These data support our conclusion that the $\mathrm{Ca}^{2+}$ wave in frog eggs is governed by $\operatorname{IP}_{3} R$.

The sea urchin egg is much smaller than the frog egg, but the fertilization $\mathrm{Ca}^{2+}$ wave travels at a similar velocity (23) (Fig. 4B, column 1). It passes as a spherical wavefront through an equatorial section. The region behind the wavefront showed no inhomogeneities in $\mathrm{Ca}^{2+}$ concentration, either in the egg nucleus (the egg nucleus is present in the optical section of Fig. 4B, column 1 , for example) or in subcortical regions, where it has been suggested that RyR may be relatively abundant (24). All compartments appeared to change uniformly. Microinjection of either heparin or ruthenium red reduced the amplitude and propagation velocity slightly but did not prevent the wave from crossing the egg (Fig. 4B, columns 2 and 3). Microinjection of both antagonists together led to a loss of the $\mathrm{Ca}^{2+}$ wave (Fig. 4B, column 4 ). Be- cause of the failure of the mechanical block to polyspermy in the absence of the $\mathrm{Ca}^{2+}$ wave, eggs were polyspermic under these conditions.

The specificity of $\mathrm{Ca}^{2+}$ release agonists and antagonists in sea urchin eggs and homogenates is shown in Table 1. Release of $\mathrm{Ca}^{2+}$ by RyR agonists was blocked selectively by ruthenium red, whereas heparin selectively blocked release by $\mathrm{IP}_{3}$. This selectivity was preserved between homogenates and eggs. Because calibration of absolute $\mathrm{Ca}^{2+}$ concentrations is difficult with the use of the single-wavelength confocal imaging technique, we confirmed our results with whole cell fluorescence with the $\mathrm{Ca}^{2+}$-sensitive ratio-dye fura 2 . The $\mathrm{Ca}^{2+}$ wave is represented by the rising phase of the whole cell signal, which was affected only by the simultaneous presence of heparin and ruthenium red (Fig. 4C).

The outcome of these experiments indicates that frog eggs have a single CICR mechanism that uses $\mathrm{IP}_{3} R$, whereas in sea urchin eggs both $\mathrm{IP}_{3} \mathrm{R}$ and $\mathrm{Ry} R$ contribute to the formation of $\mathrm{Ca}^{2+}$ waves. The coexistence of the two types of $\mathrm{Ca}^{2+}$ release channel was a prediction of the two-store model for $\mathrm{Ca}^{2+}$ oscillations (2) that led to the search for RyR in nonmuscle cells. In the two-store model, CICR is mediated only by RyR. Our results indicate that CICR can occur through either release channel in the same cell.

This redundancy may have advantages. Redundant $\mathrm{Ca}^{2+}$ release mechanisms allow separate modulation of the two channels by different agonists (25). The two channel types have different thresholds for $\mathrm{Ca}^{2+}$-dependent activation and inactivation (26). Differential coexpression and colocalization of $\mathrm{IP}_{3} \mathrm{R}$ and RyR (27) will generate a large number of different $\mathrm{Ca}^{2+}$ signaling phenotypes.

\section{REFERENCES AND NOTES}

1. T. A. Rooney and A. P. Thomas, Pharmacol. Ther. 49, 223 (1991): R. Jacob, Cell Calcium 11, 241 (1990); L. F. Jaffe, Proc. Natl. Acad. Sci. U.S.A 88, 9883 (1991)

2. M. J. Berridge and A. Galione, FASEB J. 2, 3074 (1988).

3. M. Endo, Physiol. Rev. 57, 71 (1977)

4. N. Ikemoto, B. Antoniu, J.-J. Kang, L. G. Meszaros, M. Ronat, Biochemistry 30,5230 (1991); T. E. Nelson and K. E. Nelson, FEBS Lett. 263, 292 (1990)

5. H. Takeshima et al., Nature 339, 439 (1989); G. A Mignery, T. C. Südhof, K. Takei, P. De Camilli, ibid. 342, 192 (1989); C. D. Ferris and S. H. Snyder, Annu. Rev. Physiol. 54, 469 (1992).

6. V. Sorrentino and P. Volpe, Trends Pharmacol. Sci. 14, 98 (1993).

7. A. Galione, H. C. Lee, W. B. Busa, Science 253, 1143 (1991)

8. A. Galione, Trends Pharmacol. Sci. 13, 304 (1992); A. Galione, Science 259, 325 (1993).

9. H. Y. Kubota, Y. Yashimoto, M. Yoneda, Y. Hiramoto, Dev. Biol. 119, 129 (1987); M. Whitaker and K. Swann, Development 117, 1 (1993); S. Miyazaki et al., Dev. Biol. 118, 259 (1986); J. E. Speksnijder, C. Sardet, L. F. Jaffe, ibid. 142, 246 (1990).

10. D. L. Clapper, T. F. Walseth, P. J. Dargie, H. C. Lee, J. Biol. Chem. 262, 9561 (1987); P. J. Dargie, M. C. Agre, H. C. Lee, Cell Regul. 1, 279 (1990).

11. L. Missiaen, C. W. Taylor, M. J. Berridge, Nature 352, 241 (1991)

12. D. C. Renard, M. B. Seitz, A. P. Thomas, Biochem. J. 284, 507 (1992); L. Missiaen, C. W. Taylor, M. J. Berridge, J. Physiol. (London) 455, 623 (1992).

13. A. McDougall, I. Gillot, M. Whitaker, Zygote 1, 35 (1993).

14. A. Galione et al., unpublished data.

15. I. Parker and Y. Yao, Proc. R. Soc. London Ser. B 246, 269 (1991); J. D. Leichleiter and D. E. Clapham, Cell 69, 283 (1992); S. DeLisle and M. J. Welsh, J. Biol. Chem. 267, 7963 (1992).

16. P. Palade, R. D. Mitchell, S. Fleischer, J. Biol. Chem. 258, 8098 (1983).

17. C. Sardet et al., Dev. Growth Differ. 34, 37 (1992). 
18. K. Swann, FEBS Lett. 278, 175 (1991).

19. W. B. Busa and R. Nuccitelli, J. Cell Biol. 100, 1325 (1985)

20. Our value was calculated on the basis of our observation that the wave propagates equatorially, which should be a lower value than the velocity of a purely cortical wave by a factor of $\pi / 2$. In previous estimates, a cortical wave was assumed.

21. D. Kline et al., Science 241, 464 (1988)

22. Mature Xenopus eggs were injected with heparin or ruthenium red in the presence of chlorobutanol $(10 \mathrm{mM})$. The eggs were then washed in F1 medium of composition: $41.25 \mathrm{mM} \mathrm{NaCl}, 1.75 \mathrm{mM}$ $\mathrm{KCl}, \quad 0.063 \mathrm{mM} \mathrm{MgCl}_{2} \cdot 6 \mathrm{H}_{2} \mathrm{O}, 0.25 \mathrm{mM}$ $\mathrm{CaCl}_{2} \cdot 2 \mathrm{H}_{2} \mathrm{O}, 0.5 \mathrm{mM} \mathrm{NaH} \mathrm{PO}_{4}, 1.9 \mathrm{mM} \mathrm{NaOH}$, and $2.5 \mathrm{mM}$ Hepes (acid); $\mathrm{pH} 7.8$ (19), and fertilization was attempted by addition of a sperm suspension in F1. We assessed fertilization by viewing the formation of a fertilization envelope and the contraction of the pigmented hemisphere toward the animal pole (21).

23. K. Swann and M. J. Whitaker, J. Cell Biol. 103, 2333 (1986)

24. S. M. McPherson et al., ibid. 116, 1111 (1992)

25. A. Sanchez-Bueno and P. H. Cobbold, Biochem. J. 291, 169 (1993)

26. I. Bezprozvanny, J. Watras, B. E. Ehrlich, Nature 351, 751 (1991)

27. G. Giannini, E. Clementi, R. Ceci, G. Marziali, V Sorrentino, Science 257, 91 (1991); P. D. Walton et al., J. Cell Biol. 113, 1145 (1991).

28. Xenopus egg homogenates were prepared as described for sea urchin eggs (7) but with the following modifications: We removed egg jelly by swirling the eggs in F1 cysteine medium (19), and the eggs were washed in $\mathrm{Ca}^{2+}$-free $\mathrm{F} 1$ containing $5 \mathrm{mM}$ EGTA. The eggs were homogenized in a $70 \%$ intracellular medium (IM) solution (7). The resulting $20 \%$ homogenates were incubated with an ATP-regenerating system, mitochondrial inhibitors, and the fluorescent dye fura 2 (7). Portions $(1 \mathrm{ml})$ were transferred to a cuvette, and fluorescence was monitored at $510 \mathrm{~nm}$, with excitation at 340 and $380 \mathrm{~nm}$, in a Hitachi fluorimeter at $22^{\circ} \mathrm{C}$ The ratio of the signals at the two excitation wavelengths was used to determine the concentration of free $\mathrm{Ca}^{2+}$, as described in (32). Calibrations were done in the presence and absence of heparin or ruthenium red. Each experiment in Figs. 1 to 4 is representative of at least three determinations that gave similar results.

29. The effect is not trivially explained as a consequence of the amount of $\mathrm{Ca}^{2+}$ in the store because this would affect the amount of $\mathrm{Ca}^{2+}$ available for release but not an increased sensitivity to maximal $\mathrm{Ca}^{2+}$ release by an agonist (11)

30. One of three experiments is shown in each case (each was performed at $20^{\circ} \mathrm{C}$ ). Mature Xenopus eggs were obtained as described in (19). Eggs were stored in modified Barth's solution (MBS) medium containing the anesthetic chlorbutanol $(88 \mathrm{mM} \mathrm{NaCl}, 1 \mathrm{mM} \mathrm{KCl}, 2.4 \mathrm{mM} \mathrm{NaHCO}, 0.8$ $\mathrm{mM} \mathrm{MgSO}, 0.5 \mathrm{mM} \mathrm{NaH}_{2} \mathrm{PO}_{4}, 15 \mathrm{mM}$ tris acid, and $10 \mathrm{mM}$ chlorbutanol; $\mathrm{pH} 7.6$ ) to reduce hydration of the jelly coat and to prevent egg activation during microinjection. Eggs were microinjected with $\mathrm{Ca}^{2+}$ indicator (calcium green: Molecular Probes, Junction City, OR). Just before insemination, eggs were transferred to the low-salt medium, F1. Images were obtained and processed with a Leica CLSM (Leica Laserteknik, Heidelberg, Germany) microscope with 480-nm excitation and emission filters and a $\times 5$ objective. To obtain ratio images that eliminated dye concentration artifacts, we divided the experimental images pixel by pixel by a reference image obtained at the beginning of the experiment.

31. Eggs were obtained, microinjected, and fertilized, and the fura 2 signal was calibrated as described in (32). The confocal images are representative of at least five experiments for each condition Lytechinus pictus eggs were maintained at $16^{\circ} \mathrm{C}$

32. I. Crossley, K. Swann, E. L. Chambers, M. J. Whitaker, Biochem. J. 252, 257 (1988)

33. We thank $M$. Aitchison for preparing the figures, $H$.
C. Lee for CADPR, and A. Warner, J. C. Smith, and J. M. W. Slack for help with Xenopus. Supported by grants from the Medical Research Council (A.G.) and the Wellcome Trust, the Royal Society, and the Science and Engineering Research Council
(SERC) (M.W.). A.M. was a SERC Scholar. I.G. has a fellowship from the Ministère de la Recherche. France. A.G. is a Beit Memorial Fellow.

\title{
Calcium Mobilization by Dual Receptors During Fertilization of Sea Urchin Eggs
}

\author{
Hon Cheung Lee, ${ }^{\star}$ Robert Aarhus, Timothy F. Walseth
}

Fertilization is accompanied by a transient increase in the concentration of intracellular $\mathrm{Ca}^{2+}$, which serves as a signal for initiating development. Some of the $\mathrm{Ca}^{2+}$ appears to be released from intracellular stores by the binding of inositol trisphosphate $\left(\mathrm{IP}_{3}\right)$ to its receptor. However, in sea urchin eggs, other mechanisms appear to participate. Cyclic adenosine diphosphate-ribose (CADPR), a naturally occurring metabolite of nicotinamide adenine dinucleotide, is as potent as $\mathrm{IP}_{3}$ in mobilizing $\mathrm{Ca}^{2+}$ in sea urchin eggs. Experiments with antagonists of the CADPR and IP ${ }_{3}$ receptors revealed that both $\mathrm{Ca}^{2+}$ mobilizing systems were activated during fertilization. Blockage of either of the systems alone was not sufficient to prevent the sperm-induced $\mathrm{Ca}^{2+}$ transient. This study provides direct evidence for a physiological role of CADPR in the $\mathrm{Ca}^{2+}$ signaling process.

Mobilization of intracellular $\mathrm{Ca}^{2+}$ occurs in a wide variety of cellular processes and is mediated by at least two major mechanisms. One messenger molecule that links surface receptor activation to the release of $\mathrm{Ca}^{2+}$ from internal stores is $\mathrm{IP}_{3}(1)$. Another major mechanism is $\mathrm{Ca}^{2+}$-induced $\mathrm{Ca}^{2+}$ release (CICR), which is well characterized in muscle $(2,3)$ and may function in mechanisms of $\mathrm{Ca}^{2+}$ oscillation and $\mathrm{Ca}^{2+}$ wave propagation $(4,5)$. Cyclic ADP-ribose (cADPR) is a cyclic metabolite (6) synthesized by a ubiquitous enzyme, ADPribosyl cyclase $(7,8)$, that utilizes nicotinamide adenine dinucleotide $\left(\mathrm{NAD}^{+}\right)$as substrate. The cADPR molecule occurs naturally in mammalian tissues (9) and is as potent as $\mathrm{IP}_{3}$ in mobilizing $\mathrm{Ca}^{2+}$ in sea urchin eggs $(10)$ and vertebrate cells $(11,12)$. Some evidence indicates that $\mathrm{CADPR}$ may be an endogenous regulator of the CICR process (13-15).

The similarity between ligand binding to surface receptors and the sperm-egg interaction during fertilization has led to the proposal that $\mathrm{Ca}^{2+}$ mobilization associated with fertilization is similarly mediated by $\mathrm{IP}_{3}$. Indeed, phosphoinositide metabolism increased during fertilization coincident with the increase in the concentration of intracellular $\mathrm{Ca}^{2+}\left(\left[\mathrm{Ca}^{2+}\right]_{\mathrm{i}}\right)$ and the cortical exocytotic reaction $(16,17)$. Microinjection of $\mathrm{IP}_{3}$ into eggs activates a transient increase in $\left[\mathrm{Ca}^{2+}\right]_{i}$ similar to that which occurs after fertilization (18). In hamster eggs, injection of antibody to the $\mathrm{IP}_{3}$ receptor can block changes in $\left[\mathrm{Ca}^{2+}\right]_{i}$ induced by $\mathrm{IP}_{3}$ or fertilization (19). However, in sea

H. C. Lee and R. Aarhus, Department of Physiology, University of Minnesota, Minneapolis, MN 55455.

T. F. Walseth, Department of Pharmacology, University of Minnesota, Minneapolis, MN 55455.

*To whom correspondence should be addressed. urchin eggs, heparin (an antagonist for the $\mathrm{IP}_{3}$ receptor) only delays the onset of the transient increase in $\left[\mathrm{Ca}^{2+}\right]_{i}$ but does not prevent it, suggesting that other mechanisms for mobilizing $\mathrm{Ca}^{2+}$ may exist $(20$, 21).

We investigated the effects of heparin on the $\mathrm{IP}_{3}$-induced $\mathrm{Ca}^{2+}$ mobilization in intact sea urchin eggs and homogenates. In egg homogenates, $\mathrm{Ca}^{2+}$ release induced by $\mathrm{IP}_{3}(1 \mu \mathrm{M})$ was completely blocked by heparin $(0.2 \mathrm{mg} / \mathrm{ml})$ (Fig. 1) (10). However, heparin did not affect $\mathrm{Ca}^{2+}$ release induced by cADPR (Fig. 1). We used the cortical exocytotic reaction in intact eggs as an index for $\mathrm{Ca}^{2+}$ mobilization to determine the effective concentration of heparin needed to block $\mathrm{IP}_{3}$-induced $\mathrm{Ca}^{2+}$ mobilization (22). Microinjection of $\mathrm{IP}_{3}(0.15$ $\mu \mathrm{M}$, intracellular concentration) into $\mathrm{Ly}$ techinus pictus eggs induced the cortical reaction in $100 \%$ of the injected eggs $(10)$. If eggs were first microinjected with heparin [H5765 (Sigma)] at a final intracellular concentration of $1.9 \mathrm{mg} / \mathrm{ml}$ and subsequently injected with 0.12 to $0.24 \mu \mathrm{M} \mathrm{IP}_{3}$, seven out of seven of the injected eggs did not show a cortical reaction. Increasing the concentration of $\mathrm{IP}_{3}$ to $0.72 \mu \mathrm{M}$ partially overcame the block by heparin, with two eggs giving a full cortical reaction and two eggs out of a total of eight eggs injected showing a partial cortical reaction (50\%). To block $0.72 \mu \mathrm{M} \mathrm{IP}{ }_{3}$ from inducing the cortical reaction, the heparin concentration had to be increased to $4.7 \mathrm{mg} / \mathrm{ml}$ (six out of six eggs were blocked). Thus, the blockage by heparin is competitive in nature $(20,21)$. The higher effective concentration of heparin in intact eggs as compared with homogenates is likely to result 